\title{
HUBUNGAN SELF-EFFICACY DAN SIKAP POSITIF TERHADAP PRESTASI AKADEMIK SISWA SMK NEGERI 1 SIPIROK
}

\author{
Yulia Anita Siregar ${ }^{1}$, Sukatno ${ }^{2}$ \\ ${ }^{1,2}$ Program Studi Pendidikan Matematika, Fakultas Keguruan dan Ilmu Pendidikan \\ Universitas Muhammadiyah Tapanuli Selatan, Jl. Sutan Moh. Arief no. 32 Padangsidimpuan \\ 1yulis_regar@yahoo.co.id, ${ }^{2}$ sukatnosatria@yahoo.com
}

\begin{abstract}
Self-efficacy is a person's feelings, ways of thinking, self-motivation, and desire to have something, while a positive attitude means in the learning process students have a tendency to accept or reject a concept or idea, if not in accordance with his mind. Students can think and be positive if if a learning can provide real benefits for life. While the academic achievement is the result of behavioral changes that include the cognitive domain, affective domain and psychomotor domain which is a measure of student success after being given treatment or learning. This research was conducted at SMK Negeri 1 Sipirok. This study uses descriptive research method with correlational approach with the aim to know whether there is a significant relationship between self-efficacy and positive attitude toward student academic achievement. Based on the research that has been done, the research results found that there is a significant relationship between selfefficacy and positive attitude of students to the academic achievement in SMK Negeri 1 Sipirok Tapanuli Selatan but the relationship is not showing increase or decrease so it can be said academic achievement is not important enough in pushing self-efficacy and positive attitude of students.
\end{abstract}

Keywords: self-efficacy, positive attitude, achievement of student academic

\begin{abstract}
Abstrak. Self-efficacy merupakan perasaan seseorang, cara berfikir, motivasi diri, dan keinginan memiliki terhadap sesuatu, sementara sikap positif artinya dalam proses pembelajaran siswa mempunyai kecendurungan untuk menerima atau menolak suatu konsep atau ide, apabila tidak sesuai dengan fikirannya. Siswa dapat berfikir dan bersikap positif apabila apabila sebuah pembelajaran dapat memberikan manfaat nyata untuk kehidupannya. Sedangkan prestasi akademik merupakan hasil perubahan perilaku yang meliputi ranah kognitif, ranah afektif dan ranah psikomotor yang merupakan ukuran keberhasilan siswa setelah diberikan perlakuan ataupun pembelajaran. Penelitian ini dilakukan di SMK Negeri 1 Sipirok. Penelitian ini menggunakan metode penelitian deskriptif dengan pendekatan korelasional dengan tujuan untuk mengetahui apakah terdapat hubungan yang signifikan antara self-efficacy dan sikap positif terhadap prestasi akademik siswa. Berdasarkan penelitian yang telah dilakukan maka didapatkan hasil penelitian terdapat hubungan yang signifikan antara self-efficacy dan sikap positif siswa terhadap prestasi akademik di SMK Negeri 1 Sipirok Tapanuli Selatan tetapi hubungannya ialah tidak menunjukkan kenaikan ataupun penurunan sehingga dapat dikatakan prestasi akademik tidak cukup penting dalam mendorong self-efficacy dan sikap positif siswa.
\end{abstract}

Kata Kunci: self-efficacy, sikap positif, prestasi akademik siswa

\section{PENDAHULUAN}

Salah satu yang perlu diperhatikan dalam pembelajaran adalah kepercayaan diri (self-efficacy) siswa dan sikap positif siswa merupakan salah satu faktor yang diperhatikan dalam pencapaian prestasi akademik siswa. Self-efficacy dapat berupa bagaimana perasaan seseorang, cara berfikir, motivasi diri, dan keinginan memiliki terhadap sesuatu. Keyakinan tersebut menghasilkan efek yang beragam melalui empat proses utama. Yaitu kognitif, motivasi, afektif dan proses seleksi (Bandura, 1993). Dalam hal ini self-effcacy akan membantu seberapa ia akan berusaha untuk bertindak 
dalam suatu kegiatan, dan seberapa lama mampu bertahan terhadap situasi yang tidak di sukainya. Kemampuan self-efficacy yang lemah disebabkan karena seseorang sering menghindari suatu masalah yang bersifat menantang. Kemudian cenderung ragu apakah mungkin untuk menemukan solusi daripada masalah yang ia alami. Sejalan dengan hal tersebut siswa disekolah juga terbiasa menghindari tantangan, melakukan sesuatu dengan lemah, fokus pada hambatan, dan mempersiapkan diri untuk bersikap yang kurang baik. Seseorang yang salah menilai kemampuannya akan bertindak dalam suatu cara tertentu yang akan merugikan dirinya. Seseorang yang terlalu tinggi menilai kemampuannya akan melakukan kegiatan yang tidak dapat diraih yang dapat berdampak pada kesulitan dan kegagalan, sebaliknya seseorang yang menilai rendah kemampuannya akan membatasi diri dari pengalaman yang menguntungkan. Salah satu penelitian yang dilakukan Lane \& Lane (2001) yang menunjukkan bahwa prediksi self-efficacy mengatasi tuntutan intelektual dari program akademik sebesar 11,5\%. Penelitian ini menyarankan bahwa self-efficacy memiliki beberapa manfaat dalam program akademik.

Faktor lain yang dapat berkontribusi dan tidak dapat dipisahkan terhadap prestasi belajar adalah sikap positif siswa. Jika sikap positif terjadi pada kegiatan belajar maka apa yang menjadi tujuan pembelajaran akan tercapai dengan lebih baik. Tentunya hal ini secara otomatis akan berpengaruh terhadap prestasi akademiknya. Bloom (Sugiyanto, 2007) menyatakan bahwa prestasi akademik merupakan hasil perubahan perilaku yang meliputi ranah kognitif, ranah afektif dan ranah psikomotor yang merupakan ukuran keberhasilan siswa. Selain itu prestasi akademik dinyatakan sebagai pengetahuan yang di capai atau keterampilan yang dikembangkan dalam mata pelajaran tertentu di sekolah, biasanya ditetapkan dengan nilai tes. Dengan demikian dapat disimpulkan bahwa prestasi akademik adalah besarnya penguasaan bahan pelajaran yang telah dicapai siswa berupa nilai.

Sedangkan Yara (2009) mengartikan sikap sebagai konsep yang memperhatikan cara seorang individu berfikir, bertindak, dan bertingkah laku. Sikap memiliki pengaruh yang sangat penitng untuk siswa, guru, kelompok social yang berhubungan dengan individu siswa dan seluruh system di sekolah. Sikap dibentuk sebagai hasil dari beberapa pengalaman belajar. Selain itu juga dibentuk secara sederhana daengan mengikuti contoh atau pendapat orag tua, guru dan teman. Sedemikian sehingga siswa disekolah dapat dibentuk dari situasi pembelajaran, misalnya mencontoh dari sikap guru. Sikap positif artinya dalam proses pembelajaran siswa mempunyai kecendurungan untuk menerima atau menolak suatu konsep atau ide, apabila tidak sesuai dengan fikirannya. Siswa dapat berfikir dan bersikap positif apabila apabila sebuah pembelajaran dapat memberikan manfaat nyata untuk kehidupannya.

Namun pada kenyataannya sikap positif ini belum seperti apa yang diharapkan. Terbukti dengan hasil wawancara terhadap beberapa orang guru di SMK Negeri 1 Sipirok yang mengatakan bahwa siswa hanya cenderung bekerja, misalnya menyelesaikan soal apabila tidak jauh berbeda dengan contoh. Bahkan apabila diberikan sedikit perbedaan dalam soal maka mereka tidak mau berusaha untuk meyelesaikannya. Selain itu, hasil observasi terhadap siswa dalam kegiatan pembelajaran juga menunjukkan hal yang mengecewakan. Pada saat kegiatan belajar berlangsung justru tidak sedikit siswa yang acuh tak acuh, kurang bersemangat, apa lagi pada mata pelajaran yang mereka tidak senangi seperti matematika. Dengan demikian, hal ini akan mempengaruhi prestasi akademik siswa dan tujuan pendidikan yang ingin di capai jauh dari harapan yang semestinya. 
Berdasarkan pentingnya self-efficacy dan sikap positif yang dimiliki oleh para siswa, maka penulis ingin melihat hubungan antara self-efficacy dan sikap positif terhadap prestasi akademik siswa dalam bentuk kegiatan penelitian, dengan memilih judul penelitian: "Hubungan self-efficacy dan sikap positif terhadap pretasi akademik siswa di SMK Negeri 1 Sipirok".

\section{METODE}

Metode penelitian yang digunakan dalam penelitian ini adalah metode deskriptif dengan pendekatan korelasional melalui bantuan statistik SPSS dengan tujuan untuk mengetahui apakah terdapat hubungan yang signifikan antara self-efficacy dan sikap positif siswa terhadap prestasi akademik di SMK Negeri 1 Sipirok Tapanuli Selatan. Penelitian ini menggunakan skala psikologi untuk memperoleh data terkait selfefficacy, skala sikap untuk memperoleh data terkait sikap positif dan menggunakan metode dokumentasi nilai untuk mendapatkan data terkait prestasi akademik siswa.

\section{HASIL DAN PEMBAHASAN}

Data yang diperoleh dalam penelitian ini berasal dari skala self-efficacy dan skala sikap untuk mengetahui self-efficacy dan sikap positif serta nilai ujian siswa kelas XI Akuntansi I SMK Negeri 1 Sipirok tahun ajaran 2016/2017 untuk mengetahui prestasi akademik siswa. Data-data tersebut kemudian dinalaisis secara deskriptif untuk mengetahui frekuensi dari masing-masing variabel. Berikut akan diuraikan hasil masing-masing variabel:

\section{1) Self-Eficecy}

Berdasarkan hasil perhitungan yang dilakukan diperoleh rata-rata sebesar 73,6. Nilai maximum sebesar 104, nilai minimum sebesar 50, standar deviasi sebesar 15,7405 dan varians sebesar 247,7655. Pengkategorian variabel self-efficacy dapat merujuk pada rumus Janatin (2015) dalam tabel 1 berikut. Rumus ini juga berlaku untuk mengkategorikan variabel skala sikap positif dan prestasi akademik siswa.

Tabel 1. Rumus Pengkategorian Data

Keterangan:

\begin{tabular}{ccc}
\hline No & Kategori & Interval \\
\hline 1 & Tinggi & $X \geq \mu+1,0 \sigma$ \\
\hline 2 & Sedang & $\mu-1,0 \sigma \leq X<\mu+1,0 \sigma$ \\
\hline 3 & Rendah & $X<\mu-1,0 \sigma$ \\
\hline
\end{tabular}

$\mathrm{X}:$ Jumlah skor yang diperoleh siswa

$\mu:$ Mean/Rata-rata

$\sigma:$ Standar Deviasi

Berdasarkan nilai rata-rata dan standar deviasi yang diperoleh siswa, maka kategori self-efficacy siswa dapat disajikan pada tabel 2 berikut.

Tabel 2. Kategori dan Persentase self-efficacy Siswa

\begin{tabular}{ccccc}
\hline No & Kategori & Interval & Frekuensi & Persentase (\%) \\
\hline 1 & Tinggi & $\mathrm{X} \geq 89,3405$ & 7 & $23,333 \%$ \\
\hline 2 & Sedang & $57,8595 \leq \mathrm{X}<89,3405$ & 18 & $60 \%$ \\
\hline 3 & Rendah & $\mathrm{X}<57,8595$ & 5 & $16,667 \%$ \\
\hline & Jumlah & 30 & $100 \%$ \\
\hline
\end{tabular}


Berdasrkan hasil pengkategorian dan persentase self-efficacy diperoleh 7 siswa kategori tinggi (23,333\%), 18 siswa kategori sedang (60\%), dan 5 siswa pada kategori rendah $(16,667 \%)$. Oleh karena itu, dapat disimpulkan bahwa sebagian besar siswa kelas XI Akuntansi I SMK Negeri 1 Sipirok memiliki self-efficacy kategori sedang dengan jumlah frekuensi terbanyak. Adapun sebaran dari masing-masing kategori dapat dilihat pada gambar 1 berikut.

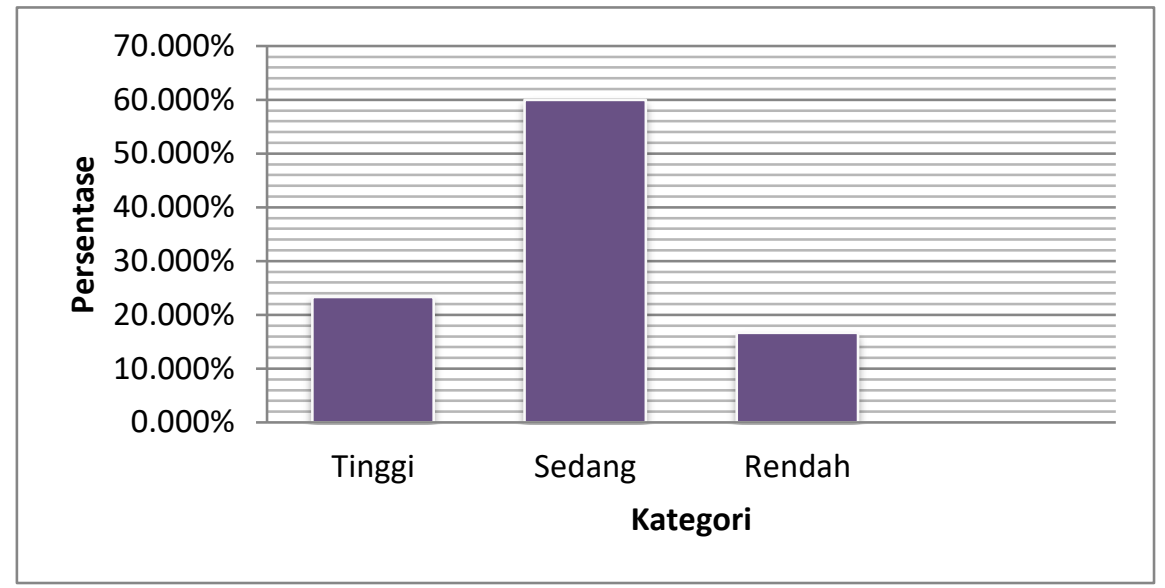

Gambar 1. Grafik Kategorisasi self-efficacy Siswa

\section{2) Sikap Positif}

Berdasarkan hasil perhitungan yang dilakukan diperoleh rata-rata sebesar 79,5. Nilai maximum sebesar 109, nilai minimum sebesar 51, standar deviasi sebesar 17,20 dan varians sebesar 295,8448. Pengkategorian variabel sikap positif dapat merujuk pada rumus Janatin (2015) dalam tabel 1 sebelumnya. Berdasarkan nilai rata-rata dan standar deviasi yang diperoleh siswa, maka kategori sikap positif siswa dapat disajikan pada tabel 3 berikut.

Tabel 3. Kategori dan Persentase Sikap Positif Siswa

\begin{tabular}{ccccc}
\hline No & Kategori & Interval & Frekuensi & Persentase (\%) \\
\hline 1 & Tinggi & $X \geq 96,7$ & 15 & $50 \%$ \\
\hline 2 & Sedang & $62,3 \leq X<96,7$ & 9 & $30 \%$ \\
\hline 3 & Rendah & $X<62,3$ & 6 & $20 \%$ \\
\hline \multicolumn{2}{c}{ Jumlah } & 30 & $100 \%$ \\
\hline
\end{tabular}

Berdasrkan hasil pengkategorian dan persentase sikap positif diperoleh 15 siswa kategori tinggi (50\%), 9 siswa kategori sedang (30\%), dan 6 siswa pada kategori rendah (20\%). Oleh karena itu, dapat disimpulkan bahwa setengah dari siswa kelas XI Akuntansi I SMK Negeri 1 Sipirok memiliki sikap positif kategori tinggi dengan jumlah frekuensi terbanyak. Adapun sebaran dari masing-masing kategori dapat dilihat pada gambar 2 berikut. 


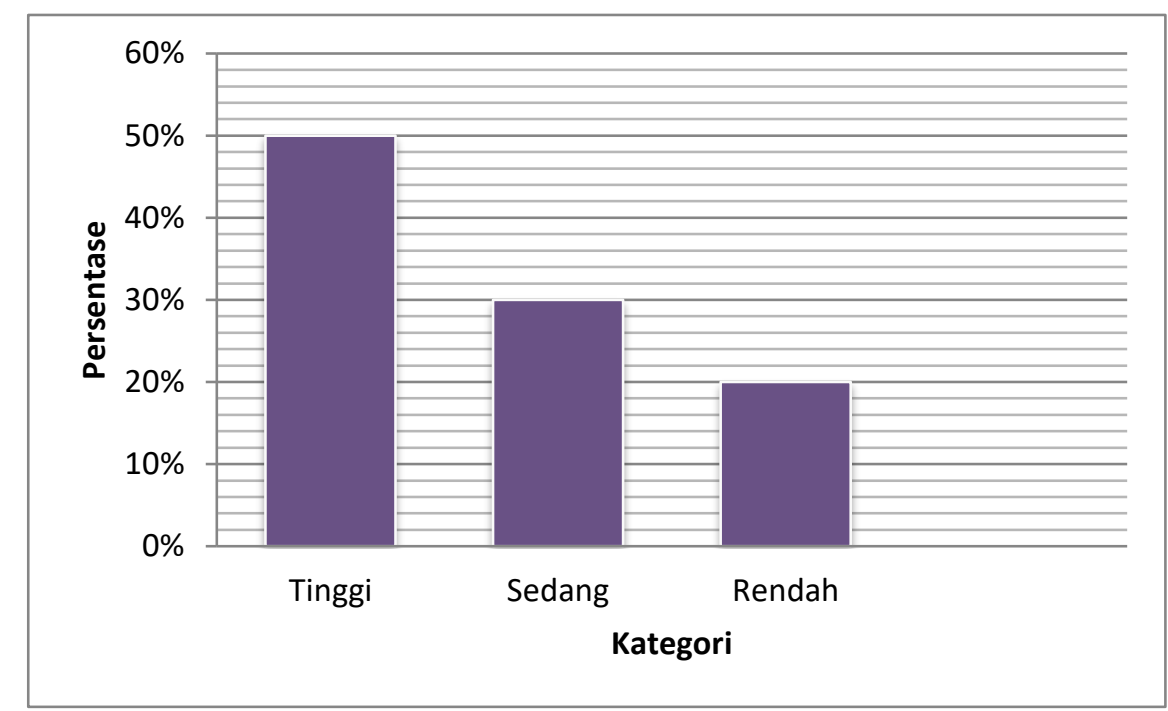

Gambar 2. Grafik Kategorisasi Sikap Positif Siswa

\section{3) Prestasi Akademik Siswa}

Untuk mengetahui prestasi belajar siswa maka dilihat dari nilai ujian siswa kelas XI Akuntansi I SMK Negeri 1 Sipirok semester genap tahun ajaran 2016/2017 yang diambil dari dokumentasi guru di sekolah pada mata pelajaran Matematika. Berdasarkan hasil perhitungan diperoleh rata-rata sebesar 80,667. Nilai maximum sebesar 95, nilai minimum sebesar 77, standar deviasi sebesar 18,289 dan varians sebesar 334,483. Pengkategorian variabel prestasi akademik siswa dapat merujuk pada rumus Janatin (2015) yang ada dalam tabel 1 sebelumnya. Berdasarkan nilai rata-rata dan standar deviasi yang diperoleh siswa, maka kategori Prestasi akademik siswa dapat disajikan pada tabel 4 berikut.

Tabel 4. Kategori dan Persentase Prestasi Akademik Siswa

\begin{tabular}{ccccc}
\hline No & Kategori & Interval & Frekuensi & Persentase (\%) \\
\hline 1 & Tinggi & $\mathrm{X} \geq 98,956$ & 0 & $0 \%$ \\
\hline 2 & Sedang & $62,378 \leq \mathrm{X}<98,956$ & 30 & $100 \%$ \\
\hline 3 & Rendah & $\mathrm{X}<62,378$ & 0 & $0 \%$ \\
\hline & Jumlah & 30 & $100 \%$ \\
\hline
\end{tabular}

Berdasrkan hasil pengkategorian dan persentase prestasi akademik diperoleh 0 siswa kategori tinggi (0\%), 30 siswa kategori sedang (100\%), dan 0 siswa pada kategori rendah $(0 \%)$. Oleh karena itu, dapat disimpulkan bahwa seluruh siswa kelas XI Akuntansi I SMK Negeri 1 Sipirok memiliki potensi akademik kategori sedang dengan jumlah frekuensi sebanyak 30 orang. Adapun sebaran dari masing-masing kategori dapat dilihat pada gambar 3 berikut. 


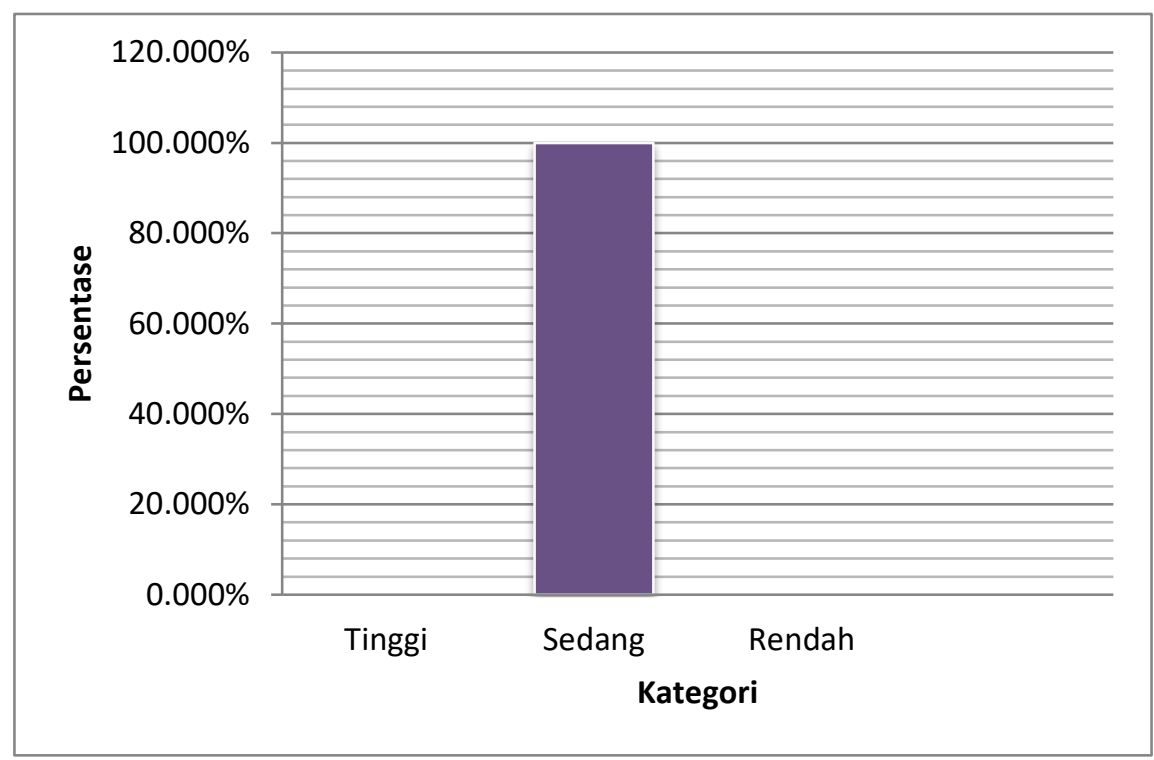

Gambar 3. Grafik Kategorisasi Potensi Akademik Siswa

Pengujian hipotesis pada penelitian ini menggunakan rumus korelasi parsial dengan bantuan SPSS. Sebelum melanjutkan pengujian terlebih dahulu merumuskan hipotesis. Berikut adalah hipotesis dalam penelitian ini:

$\mathrm{H}_{1}$ : Terdapat hubungan yang signifikan antara self-efficacy dan sikap positif siswa terhadap prestasi akademik di SMK Negeri 1 Sipirok Tapanuli Selatan

$\mathrm{H}_{0}$ : Tidak terdapat hubungan yang signifikan antara self-efficacy dan sikap positif siswa terhadap prestasi akademik di SMK Negeri 1 Sipirok Tapanuli Selatan. 5 berikut:

Berdasarkan hasil analisis SPSS diperoleh Output perhitungan seperti pada tabel

Tabel 5. Hasil Analisis Korelasi antara Self-Efficacy dan Sikap Positif Siswa Terhadap Prestasi Akademik

\begin{tabular}{|c|c|c|c|c|c|}
\hline \multicolumn{3}{|c|}{ Control Variables } & \multirow{2}{*}{$\begin{array}{r}\text { self-efficacy } \\
1,000\end{array}$} & \multirow{2}{*}{$\begin{array}{r}\text { Sikap positip } \\
, 982\end{array}$} & \multirow{2}{*}{$\begin{array}{r}\begin{array}{r}\text { Prestasi } \\
\text { Akademik }\end{array} \\
-, 089\end{array}$} \\
\hline \multirow{9}{*}{- none $^{-a}$} & \multirow{3}{*}{ Self-efficacy } & Correlation & & & \\
\hline & & Significance (2-tailed) & & ,000 & ,641 \\
\hline & & df & 0 & 28 & 28 \\
\hline & \multirow{3}{*}{ Sikap positip } & Correlation & 982 & 1,000 &,- 122 \\
\hline & & Significance (2-tailed) & ,000 & 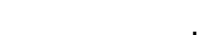 & ,522 \\
\hline & & df & 28 & 0 & 28 \\
\hline & \multirow{3}{*}{$\begin{array}{l}\text { Prestasi } \\
\text { akademik }\end{array}$} & Correlation &,- 089 &,- 122 & 1,000 \\
\hline & & Significance (2-tailed) & 641 & ,522 & \\
\hline & & df & 28 & 28 & 0 \\
\hline \multirow{6}{*}{$\begin{array}{l}\text { Prestasi } \\
\text { akademik }\end{array}$} & \multirow{4}{*}{ Self-efficacy } & Correlation & 1,000 & 982 & \\
\hline & & Significance (2-tailed) & . & ,000 & \\
\hline & & df & 0 & 27 & \\
\hline & & Correlation & 982 & 1,000 & \\
\hline & \multirow[t]{2}{*}{ Sikap positip } & Significance (2-tailed) & ,000 & . & \\
\hline & & df & 27 & 0 & \\
\hline
\end{tabular}

a. Cells contain zero-order (Pearson) correlations. 
Berdasarkan tabel di atas dapat dilihat bahwa nilai signifikan yang digunakan SPSS adalah 0,05. Jika diperhatikan hasil masing-masing dari variabel self-efficacy dan sikap positif terhadap prestasi akademik yaitu hubungan self-efficacy terhadap prestasi akademik dengan $\mathrm{df}=28$ didapat $r_{\text {tabel }}=0,374$ sedangkan nilai $r_{\text {hitung }}=-0,089$, tanpa melihat nilai negatif (arah) maka diperoleh $\mathrm{r}_{\text {hitung }}<\mathrm{r}_{\text {tabel }}$ yaitu $0,089<0,374$ dan taraf signifikan yang diperoleh ialah 0,641 maka diperoleh $0,641>0,05$ ini berarti selfefficacy tidak ada korelasi yang signifikan terhadap prestasi akademik siswa. Sedangkan untuk sikap positif dengan $\mathrm{df}=28$ didapat $\mathrm{r}_{\text {tabel }}=0,374$ sedangkan nilai $\mathrm{r}_{\text {hitung }}=-0,122$, tanpa melihat nilai negatif (arah) maka diperoleh $\mathrm{r}_{\text {hitung }}<\mathrm{r}_{\text {tabel }}$ yaitu $0,122<0,374$ dan taraf signifikan yang diperoleh ialah 0,522 maka diperoleh 0,522 > 0,05 ini berarti sikap positif tidak ada korelasi yang signifikan terhadap prestasi akademik siswa.

Sedangkan jika dilihat dari penggabungan kedua variabel self-efficacy dan sikap positif siswa yaitu bagian pertama menunjukkan bahwa koefisien korelasi antara selfefficacy dan sikap positif ialah $r_{\text {hitung }}=0,982$ dan $r_{\text {tabel }}=0,374$ maka diperoleh $r_{\text {hitung }}>$ $r_{\text {tabel }}$ yaitu $0,982>0.374$ dan nilai signifikansi 0,00 maka $0,00<0,05$ yang berarti selfefficacy dan sikap positif mempunyai korelasi yang signifikan. Sementara jika dilihat bagian kedua menunjukkan bahwa koefisien korelasi antara self-efficacy dan sikap positif sama nilainya dengan bagian pertama tidak ada perubahan baik dilihat dari segi korelasi dan signifikansinya berarti kesimpulannya sama. Berdasarkan analisis dari penggabungan variabel self-efficacy dan sikap positif terhadap prestasi akademik maka pengujian hipotesisnya ialah terima $\mathrm{H}_{1}$ dan tolak $\mathrm{H}_{0}$ yang berarti terdapat hubungan yang signifikan antara self-efficacy dan sikap positif siswa terhadap prestasi akademik di SMK Negeri 1 Sipirok Tapanuli Selatan tetapi hubungannya ialah tidak menunjukkan kenaikan ataupun penurunan sehingga dapat dikatakan prestasi akademik tidak cukup penting dalam mendorong self-efficacy dan sikap positif siswa.

\section{KESIMPULAN DAN SARAN \\ Kesimpulan}

Dari hasil analisis yang sudah dilakukan tentang hubungan antara self-efficacy dan sikap positif terhadap prestasi akademik siswa, maka diperoleh kesimpulan bahwa:

1. Tidak ada korelasi yang signifikan self-efficacy terhadap prestasi akademik siswa.

2. Tidak ada korelasi yang signifikan sikap positip terhadap prestasi akademik siswa.

3. Terdapat hubungan yang signifikan antara self-efficacy dan sikap positif siswa terhadap prestasi akademik di SMK Negeri 1 Sipirok Tapanuli Selatan tetapi hubungannya ialah tidak menunjukkan kenaikan ataupun penurunan sehingga dapat dikatakan prestasi akademik tidak cukup penting dalam mendorong selfefficacy dan sikap positif siswa.

\section{Saran}

Berdasarkan hasil yang diperoleh dalam penelitian ini, maka peneliti menyarankan:

1. Bagi guru-guru yang ingin mengajar tidak usah terlalu memikirkan hubungan selfefficacy dan sikap positif terhadap prestasi akademik siswa karena berdasarkan hasil yang diperoleh ternyata hubungannya ialah tidak menunjukkan kenaikan ataupun penurunan sehingga dapat dikatakan prestasi akademik tidak cukup penting dalam mendorong self-efficacy dan sikap positif siswa. 
2. Untuk melakukan penelitian yang lain di sekolah yang berbeda dan di kelas yang berbeda guna memastikan kesimpulan yang sudah diperoleh saat ini.

\section{UCAPAN TERIMAKASIH}

Pada kesempatan ini peneliti mengucapkan terima kasih kepada: Direktorat Riset dan Pengabdian Masyarakat Direktorat Jenderal Penguatan Riset dan Pengembangan Kementerian Riset, Teknologi, dan Pendidikan Tinggi yang telah memeberikan bantuan dana, Universitas Muhammadiyah Tapanuli Selatan, LPPM Universitas Muhammadiyah Tapanuli Selatan dan SMK Negeri 1 Sipirok Tapanuli Selatan.

\section{DAFTAR PUSTAKA}

Bandura, A. 1993. Perceived Self-Efficacy in Cognitive Development and Functioning.http://www.centerforefficacyandresiliency.org/assets/docs/Perceiv ed Self-Efficacy in Cognitive Development and Functioning.pdf

Janatin. 2015. Hubungan Antara Self-efficacy Dengan Prestasi Belajar Siswa Kelas IV SD Se-Gugus II Kecamatan Bantul Tahun Ajaran 2014/2015. Skripsi. Program Studi Pendidikan Guru Sekolah Dasar, Jurusan Pendidikan Pra Sekolah Dan Sekolah Dasar, Fakultas Ilmu Pendidikan, Universitas Negeri Yogyakarta, Yogyakarta.

Lane, J \& Lane A. 2001. Self-efficacy and Academic Performance. Social Behavior and Personality. Journal of society for Personality Research. 7(1).

Sugiyanto. 2007. Model-model pembelajaran Inovatif. Surakarta: Panitia Sertifikasi Guru Rayon 13 FKIP UNS.

Yara, Philias Olatunde. 2009. Relationship between Teachers Attitude and Students Academic Aachievement in Mathematics in Some Selected Senior Secondari School in Shoutwestern Nigeria. European Journal of Scholl Sciences. 11(3). 